\title{
Ecology and management issues of Mikania micrantha in Chitwan Naitonal Park, Nepal
}

\author{
Loknath Sapkota ${ }^{1}$
}

\begin{abstract}
Mikania micrantha, one of the worst invasive weeds in the world, is a plant of Neotropical origin and threatening to the ecosystem of most countries within the moist tropical zones of south east Asia. Three habitat types were taken to study the ecology and management issues of the weed. The study was conducted from October, 2006 to February, 2007 taking random sampling intensity of $0.3 \%, 0.03 \%$ and $0.0012 \%$ of the invaded area for tree, shrub and herb, respectively and plot size were $20^{\star} 25 \mathrm{~m}, 5^{*} 5 \mathrm{~m}$ and $1 * 1 \mathrm{~m}$, accordingly. The riparian, edge, grassland with sparse tree and shrub, low canopy area of natural and afforested forest were found to be highly invaded by the weed. A total of 102 plant species were affected in various degrees by the weed. The highest invasion was found in Dalbegia sissoo tree in afforested land and the prevalent effect was observed in Bombax ceiba of below $17 \mathrm{~cm} \mathrm{DBH}$. Most of the trees of above $30 \mathrm{~cm}$ DBH were found to be low invasion. All the shrub species in invaded area were highly smothered and only some herbs like Ageratum conizoides, Aquisetum debile, Eragrostis unioloides, Diplazium esculentum and Tectoria macrodonta were observed to be exposed.
\end{abstract}

Coevolved rust pathogen, Puccinia spegazzini has been reported to be able to control the weed. Managing grassland, the intensive and extensive production of NTFP in community forest, cutting of nutrients and moisture for climber and mulching on creeper of Mikania and introduction of parasite plant like Cuscuta reflexa have shown as appropriate measure to keep up the weed in acceptable level.

Keywords: Invasive, Puccinia spegazzini, Mulching, Control, Threatening, Smothered.

$\boldsymbol{M}$

Thania micrantha H.B.K. (Asteraceae) is a perennial, sprawling vine with a wide distribution in the Neotropics, which extends from Mexico to Argentina (Holmes, 1982). Within this native range it is restricted mostly to riparian habitats, typically occurring around the margins of rivers, lakes and marshy terrain and is rarely invasive (Cock 1982, Bareto and Evans, 1995). In sharp contrast, throughout its exotic Palaeotropical range, Mikania micrantha is an extremely serious weed with an exceptionally fast growth rate, $8-9 \mathrm{~cm} / \mathrm{day}$ (Choudhury, 1972) and it justifiably has earned the common name of mile-a minute weed (Holm et al., 1977). M. micrantha damages or kills other plants by cutting out the light and smothering them. It also competes for water and nutrients, but perhaps even more importantly, it is believed that the plant releases substances that inhibit the growth of other plants (Ye and Xia, 2001).

Mikania micrantha weed has been nominated as among 100 of "world's worst" invader (Lowe et al, 2000) and recently, March 2002 and 2004 Oceania (Pacific
Ocean countries), ranked among their top 10 worst weeds at two regional technical meetings on plant protection and insecurity (Bhuju et al., 2006). Further more, this weed is one of the three worst weeds of tea in India and Indonesia and of rubber in Sri Lanka and Malaysia. In Samoa, incursions of $M$. micrantha have caused the abandonment of coconut plantations, and the weed has been reported to kill large bread fruit trees. It also causes serious problems in oil palm, banana, cacao and forestry crops, and in pastures (http://www.issg.org/ database/welcome/).

Likewise, Mikania micrantha is assessed as one of the six high risk posed invasive alien species in Nepal (Tiwari et al, 2005) and later on, considered to be the most problematic in terrestrial ecosystem in eastern and central Nepal (Poudel et al., 2005). In Chitwan National Park (CNP), Mikania micrantha was found to be the most serous weed among the eight invasive alien species (IAS) in terrestrial ecosystem (Sapkota, 2006).

It has been well documented that IAS are the second greatest threat to biological diversity globally and the 
highest threat on many island ecosystems. There are also enormous economic losses incurred due to the impacts of invasive species. The Convention on Biological Diversity (CBD) recognizes the importance of this global issue and calls on contracting parties to "prevent the introduction of, control or eradicate those alien species that threaten ecosystems, habitats and species" Article 8 (h) (Neville, 2001). IAS are particularly serious in the developing world, where they are compounding a multitude of problems affecting livelihoods. However, in many countries and regions, lack of quantitative impact data and a measure of the scale of the problems is hindering appropriate actions at the national level. There is a need to establish cross-sectorial linkages on IAS, in order to facilitate cooperation and share experiences in appropriate control technologies (Ellison et al., 2005).

The present study, thus, aims to assess the area of invasion and invasibility in the study area, and biomass of the weed along with diversity, composition, density and frequency of species in invaded area as well as management options for the weed.

\section{Materials \& methods}

\section{Site description}

$\mathrm{CNP}$, covering the total area of $1682 \mathrm{~km}^{2}$ (core area 932 and buffer zone area $750 \mathrm{~km}^{2}$ ), lies in the lowlands of central Nepal and is located between $27^{\circ} 16^{\prime} 56^{\prime \prime}$ $\mathrm{N}$ to $27^{\circ} 42^{\prime} 13^{\prime \prime} \mathrm{N}$ latitude and $83^{\circ} 50^{\prime} 23^{\prime \prime}$ to $84^{\circ} 46^{\prime}$ 25 "E longitude. The park established in 1973 as the first protected area in Nepal has a long history of over 3 decades in park management and rich experiences in nature conservation (Shrestha, 2006). It is an important habitat for a large number of endangered mammals like one horned Rhinoceros, Royal Bengal Tiger, Asiatic Elephant, sloth Bear, Gaur and a number of birds like the Giant Hornbill, Bengal florican, lesser florican, and reptiles like the Gharial and the Mugger crocodiles. The park has over seven types of forests, six types of grasslands, three main rivers systems, a number of oxbow lakes and wetlands which support 50 species of mammals, 526 species of birds, 49 species of reptiles ands amphibians and 120 species of fishes. Floral diversity encompasses over 600 species of which 50 are grasses, 16 orchids and 73 ferns. It provides a natural linkage to the Mahabharat range on its north, the Siwaliks hills and the Terai forests towards the south and the Parsa Wildlife Reserve in the east. The Terai of Chitwan bordered with Indian territory making the transboundary linkage with the Valmiki Tiger Sancuary, Udaipur Sanctuary and Sohagibarwa Sanctuary (DNPWC/HMGN, 2002). In recognition of its unique biological resources of outstanding universal value, United Nations Education, Scientific and Cultural Organization (UNESCO) designated the park as a World Heritage Site and the Beeshazari Tal contained within the park system is included in a Ramsar Site (Shrestha, 2006).

The study was carried out in Icharni island of core zone and Jankauli buffer zone community forest in Sauraha area of the park (latitude: $27^{\circ} 35^{\prime}$ North and longitude: $84^{\circ} 29^{\prime}$ East) which cover the total area of 459 hectares. The island is surrounded by Rapti river in the east, south and west, and Dhungre Khola in the north whereas Jankauli community forest lies at the north adjacent to the island and separated by Dhugnre Khola. The study area comprises various habitat types such as grassland (220 ha.), riverine forest (174 ha.) and afforested land (65 ha.).

\section{Data collection}

Reconnaissance survey was carried out to identify the invaded area of each habitat. The habitat wise coordinates recorded through Geographic Positioning system (GPS) were transferred into satellite image available from Google earth. Then, the invaded areas of each habitat were isolated into blocks. One block of 56 ha from afforested land, three blocks of total area of 77 ha from grassland and five blocks of total area of 104 ha from riverine woodland were assessed as invasion of the weed. Each block was divided into various quadrates of $20 * 25 \mathrm{~m}$ and these quadrates were randomly selected from each block so that representing $0.3 \%$ sampling intensity of invaded areas as 4 from afforested land, 5 from grassland and 7 from riverine woodland for tree species and invasion ability of Mikania. Within these quadrates, two $5 * 5 \mathrm{~m}$ quadrates were allocated randomly in two corners of each quadrate for the shrubs and Mikania biomass representing 0.03\% sampling intensity. Likewise herbs and regeneration were recorded from nesting sampling of $1 * 1 \mathrm{~m}$ quadrate within the $5 * 5 \mathrm{~m}$ quadrate representing $0.0012 \%$ intensity.

All plant species within each quadrate were identified and counted. Since the countless number of branches with sufficient length, climbing, creeping and highly spreading nature and entangled form of Mikania and its associate climbers: the actual discrete number of 
all climber could not be assessed and indirect method as number of invaded tree and the climber species found in the tree were considered to be the number of plants and species accordingly. In case of grassland, Mikania was assumed to be $25 \mathrm{~m}^{2} /$ plant in $100 \%$ coverage as reported by Tiwari et al., (2005). The plant species were identified with the help of standard literature of plant identification in Nepal and visual inspection by taxonomists. Herbarium in National Trust for Nature Conservation in Sauraha, Chitwan was consulted for the further identification of the species. Invasion quantity of Mikania on individual tree was ranked in 4 categories depending on percentage of smothering on the tree by the weed. Following criteria were considered for the ranking: non invasion, low (01-30\%), moderate (31-50\%), high (more than $51 \%$ ). The green biomass of Mikania was taken with spring weight from each quadrate of $5 * 5 \mathrm{~m}$ and $1 \%$ of green biomass sample was subjected to sun dry then oven dry at $70^{\circ}$ Celsius for 24 hours. Electronic weight was taken before and after the oven dry.

Furthermore, the pulled out heap of Mikania from four quadrates was used as mulching over the creeper of the adjacent weed, and thread like stems of parasitic plant (cuscuta reflexa) were introduced on Mikania invaded area in four places. Both of the measure were carried out simultaneously in separate places of JCF and their effects on weed were observed for four months (September, 2006 to January, 2007) to see whether these measure could be used as control option. In addition, open interview from local key person, farmers, nature guides and park personnel along with literature and document survey as well as consultation to Invasive Species Specialist Group (ISSG) and Centre for Agriculture and Bioscience International (CABI) were consulted for other control options of the weed.

\section{Statistical analysis}

\section{Simpson's Index of Diversity 1 - D}

$\mathrm{D}=\frac{\sum \mathrm{n}(\mathrm{n}-1)}{\mathrm{N}(\mathrm{N}-1)} \quad$\begin{tabular}{l|}
$\mathrm{D}=$ Simpson's Index \\
$\mathrm{n}=$ the total number of plants of a \\
particular species \\
$\mathrm{N}=$ the total number of plants of all species
\end{tabular}

Density of species $=\frac{\text { Total number of individuals of a species }}{\text { Total number of quadrates sampled } \mathrm{x} \text { size of a quadrate }}$

Relative density $=\frac{\text { Total number of individuals of a species }}{\text { Total number of individuals of all species }}$

Frequency $=\frac{\text { Total no. of quadrates in which a particular species occurs }}{\text { Total number of quadrates sampled }} \times 100$
Relative Frequency $=\frac{\text { Frequency of a species }}{\text { Sum of frequency values for all species }} \times 100$

In situ biomass of Mikania derived from each quadrate of $5 \mathrm{~m} * 5 \mathrm{~m}$ was interpreted to the whole biomass of the study area.

\section{Results and discussions}

\section{Invasion of the weed}

The weed shows the interesting characters in relation of sun light. The invasion was observed decreases with the increases of canopy closure on one hand and almost absent in 100\% open grassland (without tree and shrub) on the other. It was found intensely growing in open patches of woodland.

86\% Jankauli Community Forest (JCF) is invaded by Mikania. Entire grassland (without any tree and shrub) of the forest which lies in southern boundary along the bank of Dhugre Khola is free from the weed. The grassland without fence isolated from woodland seems to be left for open grazing is lacking the weed due to the heavy pressure of cattle. Most of the woodland enclosed with barbed fencing (except small piece with turmeric farming in around the JCF office building and in western part isolated by wide road) received contiguous invasion of the weed. The contiguous invasion of Mikania is attributed due to the regular (once a year) opening of canopy through thinning and pruning of the forest by forest user group (FUG). In case of Icharni island, $60 \%$ and $35 \%$ of woodlands and grasslands are affected by the weed respectively. The invasion of Mikania was observed along the river bank and edge because these are the preferable habitats of the weed in its native range as stated by Cock (1982), and Bareto and Evans (1995) and low canopy area of woodland. In contrast of JCF, the distribution of the weed was observed in various patches in the woodland due to the canopy closure ranges from more than $80 \%$ to less than $25 \%$. Whereas, the moist grassland with sparse tree and shrub was found to be highly favorable for the weed. The southern part of the grassland is less invaded as compared to northern and western part and it is attributed that the grass land is also used for grazing because of easy accessible due to the open boundary from community grazing land of Kumrose buffer zone community forest.

Most of the small trees, shrubs and herbs were severely smothered in the invaded area and only some herbs like Ageratum conizoides, Eragrostis unioloides, 
Aquisetum debile, Diplazium esculentum, Lepisorus bicolor and Tectoria macrodonta were observed to be able to penetrate out through the entangled form of Mikania. The former three are also considered as invasive plants and later three (ferns) are profoundly growing in their habitat. These could be the reasons behind the phenomena. Imperata cylindrica and Saccharum spontaneum, were found to be dead and no new culms were sprouting from the rootstock in the invaded area. The invasion quantity on major tree species were assessed as follows.
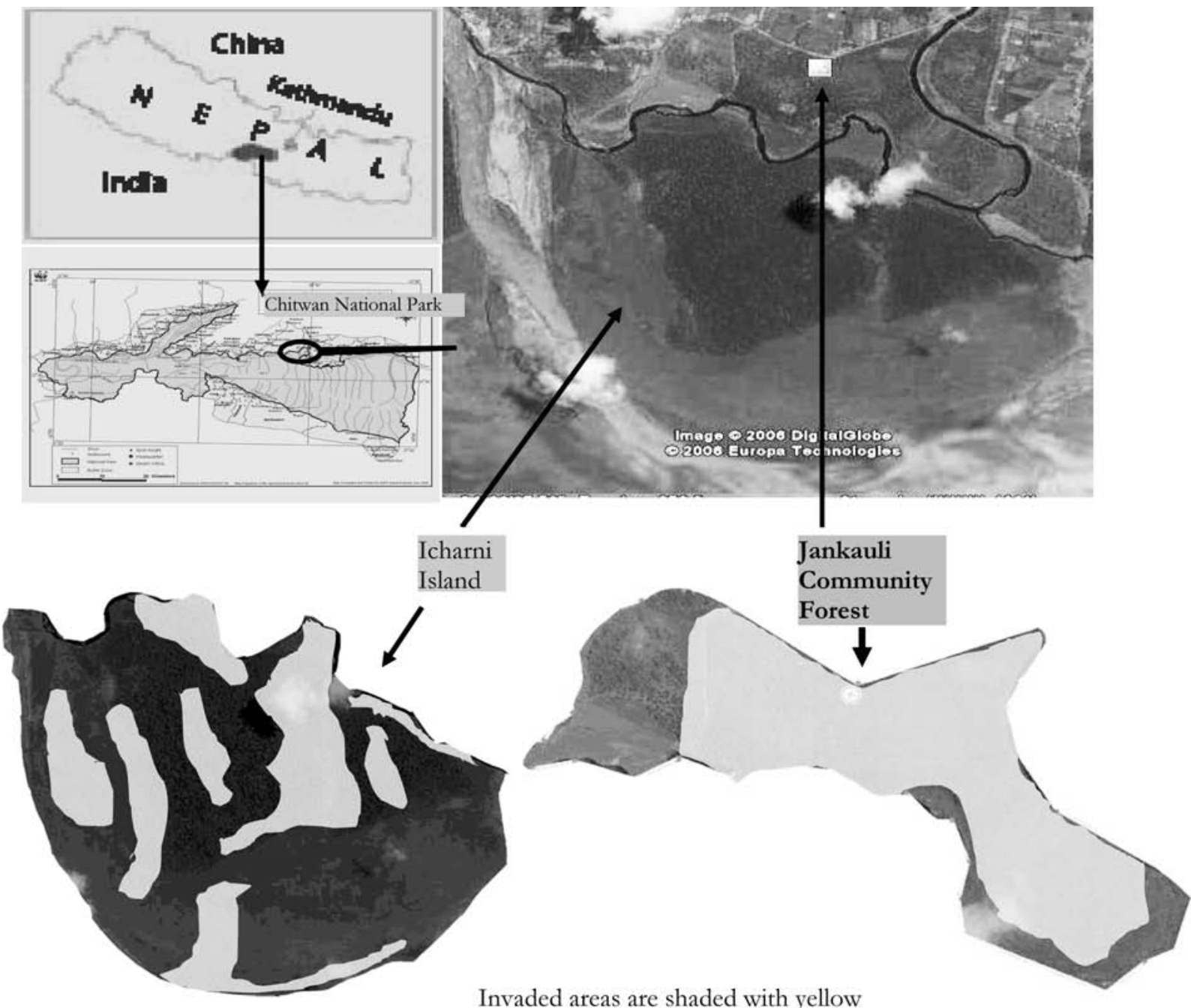

Figure 1: showing the study Area and distribution of Mikania 
Table 1: Assessment of invasion ability on major tree species.

\begin{tabular}{|c|c|c|c|c|c|c|}
\hline \multirow{2}{*}{ S.N. } & \multirow{2}{*}{ Species } & \multicolumn{4}{|c|}{ Invasion quantities } & \multirow{2}{*}{ Remark } \\
\hline & & None & Low & Medium & High & \\
\hline 1 & Bombax ceiba & $18 \%$ & $9 \%$ & $2 \%$ & $71 \%$ & $\begin{array}{l}18 \% \text { of the highly invaded below } \\
17 \mathrm{~cm} . \text { DBH were dead and most } \\
\text { of the tree above } 30 \mathrm{~cm} . \mathrm{DBH} \\
\text { were none or less invaded. }\end{array}$ \\
\hline 2 & Dalbergia sissoo & 0 & 0 & 0 & $100 \%$ & $\begin{array}{l}\text { DBH ranges from } 7 \text { to } 24 \mathrm{~cm} \text { and } \\
15 \% \text { were dead }\end{array}$ \\
\hline 3 & Trewia nudiflora & $41 \%$ & $9 \%$ & $2 \%$ & $48 \%$ & $\begin{array}{l}\text { No dead tree was found and the } \\
\text { trees with more than } 35 \mathrm{~cm} \text { DBH } \\
\text { were low or none invaded }\end{array}$ \\
\hline 4 & Litsea monopetala & $2 \%$ & $3 \%$ & $6 \%$ & $89 \%$ & $\begin{array}{l}\text { No dead tree was found and all } \\
\text { sizes trees were invaded }\end{array}$ \\
\hline 5 & Premna barbata & $6 \%$ & $13 \%$ & $0 \%$ & $81 \%$ & No dead \\
\hline 6 & Ehretia elliptica & $27 \%$ & $3 \%$ & $8 \%$ & $62 \%$ & No dead \\
\hline 7 & Acacia catechu & $0 \%$ & $0 \%$ & $0 \%$ & $100 \%$ & $3 \%$ were dead \\
\hline 8 & Myrsine chisia & $25 \%$ & $4 \%$ & $8 \%$ & $63 \%$ & No dead \\
\hline 9 & Murraya koenigii & $20 \%$ & $15 \%$ & $0 \%$ & $65 \%$ & No dead \\
\hline
\end{tabular}

From the above table, Dalbergia sissoo and Acacia catechu are highly invaded and the impact of invasion is most serious on Bombax ceiba of below $17 \mathrm{~cm} \mathrm{DBH}$. There is no regeneration observed on Bombax in invaded area. Dalbergia sissoo and Acacia catechu are showing the same phenomena as no regeneration, were observed. Litsea monopetala, Trewia nudiflora, Ehretia elliptica and Murraya koenigii show the ability to compete with Mikania in comparison with other species since all stages of plants from seedling to matured tree were observed in invaded area. The reason behind the death of Bombax saplings could be hampering the sunlight and allelopathic effects due to the heavily smothered by the weed. The invasion of Mikania on individual tree was found almost with its associate climbers like Parthenocissus semicordata, Tetrastigma serrulatum, Trachelospermum fragrans etc and it was able to climb on small tree taking support of bushes beneath the tree and its associate climbers. Whereas the ground floors of large trees were found unfavorable for the bushes due to the shade effect as well as absent of associate climber seems to be the main causes of less or no invasion of the weed on large trees.

\section{Biomass of Mikania}

The green biomass/ unit area was found to be variable depending upon habitat types. The highest and lowest biomass was in grass land and woodland of Icharni island respectively. The green biomass ranges as 2.3 $\mathrm{kg} / \mathrm{m}^{2}$ in Icharni grassland, $1.4 \mathrm{~kg} / \mathrm{m}^{2}$ in Jankauli Community Forest and $0.56 \mathrm{~kg} / \mathrm{m}^{2}$ in Icharni woodland. The oven dry biomass decreased to $13.4 \%$ of its green weight.

\section{Diversity, composition and frequency of species}

The diversity of species was found to be the highest in wood land of Icharni island followed by second status in grass land and third in Jankauli community Forest. Table 2 shows the Simpson's Index of Diversity of each habitat.

There are total 102 species in 16 plots of three habitat types and out of which 24 species of tree, 23 species of shrub, 35 species of herb, 4 species of ferns and 16 species of climber and creeper recorded during the study. The major tree species found in the invaded woodland of JCF are Trewia nudiflora, Litsea monopetala, Dalbergia sissoo, Ehertia elliptica and Bombax ceiba followed by Pogostemon benghalensis, Callicarpa macrophylla and Achyranthus aspera etc in shrub, Eragrostis unioloides, Aquisetum debile, Ageratum conizoides and Diplazium esculentum etc in herb and associate major climbers are Parthenocissus semicordata, Trachelospermum fragrans and Piper longum whereas the major tree species of Icharni woodland are Ebretia

Table 2: Habitat types and their diversity index.

\begin{tabular}{lccc}
\hline \multicolumn{1}{c}{ Habitat types } & $\begin{array}{c}\text { JCF (afforested } \\
\text { woodland) }\end{array}$ & $\begin{array}{c}\text { Riverine Forest of Icharni } \\
\text { Island }\end{array}$ & Grassland of Icharni Island \\
\hline $\begin{array}{l}\text { Simpson's Index of } \\
\text { Diversity (1-D) }\end{array}$ & 0.786 & 0.904 & 0.817 \\
\hline
\end{tabular}


elliptica, Myrsine chisia, Litsea monopetala, Trewia nudiflora and Murraya keinigii followed by Pogostemon benghalensis, Callicarpa macrophylla, Colebrookia oppositifolia. In contrast, Coffea benghalensis was found to be prominent shrub in absence of the weed. The herb species are Eragrostis unioloides, Aquisetum debile, Diplazium esculentum, lepisorus bicolor etc and the associate climbers are Bredelia retusa, Parthenocissus semicordata, Trachelospermum fragrans etc. Likewise, major tree species in grassland are Trewia nudiflora and Litsea monopetala followed by Callicarpa macrophylla, Sida acuta and Solanum torvum etc in shrub and Imperata cylindrica, Saccharum spontaneum, Diplazium esculentum etc in herb. The associate climbers and creeper are Coccinea grandis, Parthenocissus semicordata etc.

The overall highest frequency among the tree species was found as 93.75 in Trewia nudiflora followed by Callicarpa macrophylla as 65.625 among the shrubs, Eragrostis unioloides as 43.75 among the herbs, Diplazium esculentum as 59.375 among the ferns, and both of the Mikania micrantha and Parthenocissus semicordata showed the same status as 87.5 among the climbers. The most associate climber of Mikania is Parthenocissus semicordata showing the nature of highly invasive.

\section{Density of the species}

The over all highest density of tree species was found in Litsea monopetala as 0.5 plants $/ \mathrm{m}^{2}$ followed by Myrsine chisia (0.15 plants $/ \mathrm{m}^{2}$ ) and Murraya koinigii $\left(0.13\right.$ plants $\left./ \mathrm{m}^{2}\right)$. Coffea benghalensis (21.44 plants $\left./ \mathrm{m}^{2}\right)$ showed the most abundant shrub plant but confined to woodland of riverine forest. Other abundant shrubs are Clerodendron viscosum (3.16 plants $\left./ \mathrm{m}^{2}\right)$, Pogostemon benghalensis (3.15 plants $/ \mathrm{m}^{2}$ ), Colebrookia oppositifolia (2.6 plants $/ \mathrm{m}^{2}$ ), Artemisia vulgaris (2.52 plants $/ \mathrm{m}^{2}$ ) distributed, at least, in two habitats. The major herb species in grassland are Saccharum spontaneum (9250 plants $/ \mathrm{m}^{2}$ ) and Imperata cylindrica (6406.25 plants $/ \mathrm{m}^{2}$ ). However, the over all highest density was recorded in Eragrostis unioloides (1296.875 plants $/ \mathrm{m}^{2}$ ) which is distributed in all habitats. The same nature of distribution was found in Aquisetum debile (1296.87 plants/ $\mathrm{m}^{2}$ ), Ageratum conyzoides (664.37 plants $/ \mathrm{m}^{2}$ ) which are considered to be invasive alien species. The highest density among the fern was recorded in Lepisorus bicolor (1921.8 plants $\left./ \mathrm{m}^{2}\right)$. Parthenocissus semicordata (0.46 plants $/ \mathrm{m}^{2}$ ) stands the highest density among the climber and creeper followed by Piper longum ( 0.44 plants $/ \mathrm{m}^{2}$ ) and Mikania $\left(0.13\right.$ plants $\left./ \mathrm{m}^{2}\right)$. See annex-1 for details.

\section{Control and Management Measures}

Neighboring countries, such as India and China are also affected by the weed and much more work has been conducted in this regard. The collaboration of CABI with India to control Mikania resulted in selection of co-evolved natural enemies (rust pathogen) Puccinia spegazrini to be the most appropriate long-term solution as for the control of Mikania (Ellison, 2004) and it is on the pace of success. CABI is an international organization which has conducted various researches and programs in member countries to control Mikania and other alien invasive species. There are 40 member countries including India, China, Bangladesh and Sri Lanka but unfortunately, Nepal has not yet become a member of the CABI. There are other international organizations such as Global Invasive Species Program (GISP), ISSG etc. to address the invasive weed also seems to be not consulted and hence less effort has been implied in Nepal to control the weed. Managing the grassland without tree and shrub in protected area, the intensive and extensive use of land for the production of NTFP in community forest are found to be effective for the control of the weed. Mikania plant could not sprout easily through the mulch as compared to other plant species. There were hardly 2 branch shoots $/ \mathrm{m}^{2}$ recorded after one month of mulching with pulled out heap of Mikania on adjacent creeper of the weed. The mulching material was stirred as upside down at the at the same time as first observation and no Mikania shoot was observed after 3 consecutive months whereas, other plants were sprouting through the mulching. In addition, all the Mikania branches in touch with interface and lying in between the face and ground found to be dead (see annex-2). These characteristics of the plant could be helpful to generate appropriate mechanical control in such a way that all the Mikania climbers should be cut above the ground $(1-1.5 \mathrm{~m})$ to disallow nutrient and moisture, and remaining creeper on the ground should be collected and used as mulching over adjacent creeper. In this method, relatively low labor input is required as compared to other mechanical control.

The thread like stems of Cuscuta reflexa on the smothered surface of Mikania formed haustorium on all the plant species where the stem touches. $C$. reflexa coiled around the leafstalks, stems and branches of Mikania and the stem of the parasitic plant was found to be exceptionally thick incase of haustorium on Mikania (see annex-2), whereas the Cuscuta stem 
on other plants showed normal in thickness. The infected portion of Mikania was found to be suppressed and all the dead and live plant communities beneath the smothered surface area of $3 \mathrm{~m}^{2}$, on an average, were exposed out after three months of introduction. These phenomena of the Cuscuta plat showed the highly parasitism on Mikania. Since the parasitic plant is native with higher growth rate $\left(10 \mathrm{~cm} \mathrm{day}^{-1}\right)$ than Mikania as stated by Han et al,.(2002) and the plant is experienced as less problematic elsewhere as compared to Mikania. Furthermore, The Cuscuta reflexa is reported to be the sources of Triterpines and Betunelic acid molecules with anti cancer and anti HIV properties (Poudel, 2002 in Upreti 2004). So the introduction of Cuscuta plant on Mikania invaded area could be the multiple benefits as safe and cheap control measure as well as source of producing substantial revenues.

\section{Conclusion}

Forest edge, riparian vegetation, afforested land and grassland with sparse trees and shrubs are being degraded due to high invasion of the weed. The nature of invasion and its preferred habitat show the serious threat to the environment as to alter the ecosystem unfavorable for native organism as well as reduce the resources for the subsistence user. The weed is compounding a multiple of problems affecting livelihoods and environment and furthermore, the knowledge based on the weed control and its used options is limited and the control of weed will run into serious problems if early steps are not taken to resolve the problem. So it is needless to say that Mikania micrantha should be categorized as "most serious weed" of Chitwan National Park and it needs to take immediate action to control the weed.

\section{Recommendations}

The study has come up with the following set of recommendations.

- Nepal government should give high priority to control and manage the weed. More work is needed to predict the spread of M. micrantha and the likely effectiveness of potential biological control agents. In the meantime local governments need to initiate actions to prevent the weed's further invasion. Public education will be an important activity. Public participation in manual removal programs will also remain necessary.
- International cooperation and communication should be taken as key aspect to tackle this weed and it is strongly recommended to be a member of CABI to get various supports for the control of the weed and other environmental assistance.

- Further study on mulching effects and accession of parasitic plant like Cuscuta reflexa are recommended to explore sustainable control measure of Mikania.

\section{Acknowledgements}

I am indebt to my principal advisor Prof. I.C. Dutta and co-adviser Dr. B.K. Paudyal, IOF, Pokhara for their valuable guidance. I acknowledge NepalAustralia Community Resource Management and Livelihoods Project (NACRMLP) for financial support, and Department of National Park and Wildlife Conservation for the permission to conduct study. I am indebt to Dr. Carol A. Elison (Principal Scientist, Invasive Species Management, CABIEurope, UK), Ms Shyama Pagad (IUCN SSC Invasive Species Specialist Group, University of Auckland, New Zealand), Ukesh Raj Bhuju (Nepal nature dot com), Shiva Raj Bhatta (former Chief Warden, CNP), Surya Bahadur Pandey (Conservation Officer, DNPWC), Bhawani Kharel and Dwarika Aryal (IUCN, Nepal) for their co-operation and documents support, and National Trust for Nature Conservation (NTNC), Chitwan, Nepal for providing facilities on oven dry and consultation of herbarium. Sincere thanks are also due to Dr. Hem Sagar Baral (Himalayan nature), Mr. Gopal Prasad Upadhya (former Chief Warden, CNP), Mr. Jhamak Bahadur Karki (Ecologist, DNPWC) Mr. Ram Kumar Aryal (Administration officer, NTNC), Mr. Lal Bahadur Bhandari (Ranger, CNP), Siva Kanta Lal Karna Suman (Ranger, CNP) and Lova Jang Thapa (CNP) for enthusiastic support. Many thanks go to $\mathrm{Mr}$. Harkaman Lama and Chandu (Wildlife Technician, NTNC) for instrumental support, Mr. Bal Bahadur Lama (Former Wildlife Technician, NTNC), and Mr. Rudra Bahadur Sapkota (local resident) for their help in field work and data collection. This report would not have been possible without the overwhelming response and co-operation shown by the UG of Jankauli Community Forest and other villagers of buffer zone, nature guides, Park personnel and all the respondents who shared their ingenuity knowledge and ideas with me. 
I am also thankful to Mr. K. P. Dhakal, Mr. Gandhiv Kafle, Mr. Rajesh Malla, Mr. Kedar Baral, Mr. Nagendra Prakash Regmi and all my M.Sc. colleagues who helped me during the sharing the idea about data interpretation and analysis. I would like to acknowledge those who are directly or indirectly involved in this research.

\section{References}

Bareto, R. W. and Evans H. C. 1995. The mycobiota of the weed Mikania micrantha in southern Brazil with particular reference to fungal pathogens for biological control. Mycological Research 99: 343352.

Bhuju, U. R., Shakya, P. R. and Shrestha, S. 2006. Generating Bio-Income by Curbing Plant Invasion: Case Study on Jankauli Buffer Zone Community Forest, Chitwan National Park, Nepal (October 31, 2006) Draft report submitted to the IUCN Asia Regional Office (unpublished)

Choudhury, A. K. 1972. Controversial Mikania (climber) a threat to the forests and agriculture. Indian Forester 98:178-186.

Cock, M. J. W. 1982. Potential biological control agents for Mikania micrantha HBK form the Neotropical Region. Tropical Pest Management 28:242-254.

DNPWC/MFSC. 2002. State of Conservation of specific World Heritage properties, Section II. Periodic Reporting Exercise on the Application of the World Heritage Convention. Department of National Park and Wildlife Conservation. Government of Nepal.

Ellison C. A., Murphy S. T and Rabindra R. J. 2005. Facilitating access for developing countries to invasive alien plant classical biocontrol technologies: the Indian experience. Aspects of Applied Biology 75, 2005. Pathways Out of poverty.

Ellison, C. A. 2004. Classical Biological Control of Mikania micrantha (Mile a minute weed). Case study. International Journal of Tea Science, 3.
Han, S. C., Li, K. H. and Luo, L. F., 2002. Mikania micrantha was destroyed by parasitic weed dodder, Cuscuta chinensis, in Guangdong. Natural Enemies of Insects 24: 7-14 (in Chinese).

Holm, L. G., Plucknett, D. L., Pancho J. V. and Herberger, J. P. 1977. The Worlds worst weeds. Distribution and biology. University Press of Hawaii. Honolulu.

Holmes, WC. 1982. Revision of the Old World Mikania (Compositae). Botan Jahres Beitr Systematik 103-211-246

Lowe S., Browne, M., Boudjelas, S. and Poorter, D. M. 2000. 100 of the World's Worst Invasive Alien Species. A selection from the Global Invasive Species Database.

Neville, L. 2001. Global Invasive Species Program (GISP) Update. Aliens 13: 3-6.

Poudel, A., Baral, H.S., Ellison, C. A., Subedi, K., Thomas, S. and Murphy, S. 2005. Mikania micrantha weed invasion in Nepal. A summary report of the first national workshop for stakeholders, held on 25 November, in Kathmandu, Nepal.

Poudel, Y. B. 2002. Phytochemical and biological studies on Cuscuta reflexa of Nepalese origin. [Thesis]. Kathmandu; Central Department of Chemistry, Tribhuvan University, Nepal. 120p.

Sapkota, L. N. 2006. Invasive Alien Species in Chitwan National Park, Nepal. A special study report for the partial fulfillment of M. Sc. Forestrysubmitted to Institute of Forestry, Tribhuvan University, Pokhara, Nepal (unpublished).

Shrestha, T. B. 2006. Chitwan National Park and Buffer Zone Management Plan (CNPBZMP) 2006-2011. Under the process of approval.

Tiwari, S., Adhikari, B., Siwakoti, M. and Subedi, K. 2005. An Inventory and Assessment of Invasive Alien Plant Species of Nepal, IUCN- The World Conservation Union, Nepal.

Upreti, R. 2004. Chemical research should be a national priority. Himalayan Journal of Science. 2(3). 10.

Ye, W. H. and Z. Xia, 2001. The plant killer-Mikania Micrantha in South China. Aliens 13: 7. 
Annex 1: Density and relative density of plant species in invaded area

Section 1: Density and relative density of trees (highest and lowest density values are highlighted)

\begin{tabular}{|c|c|c|c|c|c|c|c|c|c|c|}
\hline \multirow[b]{2}{*}{ S.N. } & \multirow[b]{2}{*}{ Botanical name } & \multirow[b]{2}{*}{ Local name } & \multicolumn{2}{|c|}{ JCF (Afforested land) } & \multicolumn{2}{|c|}{ Icharni woodland } & \multicolumn{2}{|c|}{ Icharni Grassland } & \multicolumn{2}{|c|}{ Overall } \\
\hline & & & $\begin{array}{l}\text { Density } \\
\mathrm{pl} / \mathrm{m}^{2}\end{array}$ & $\begin{array}{l}\text { Rel. density } \\
\%\end{array}$ & $\begin{array}{l}\text { Density } \\
\mathrm{pl} / \mathrm{m}^{2}\end{array}$ & $\begin{array}{l}\text { Rel. density } \\
\%\end{array}$ & $\begin{array}{r}\text { Density } \\
\mathrm{pl} / \mathrm{m}^{2}\end{array}$ & $\begin{array}{l}\text { Rel. density } \\
\%\end{array}$ & $\begin{array}{r}\text { Density } \\
\mathrm{pl} / \mathrm{m}^{2}\end{array}$ & $\begin{array}{r}\text { Rel. density } \\
\%\end{array}$ \\
\hline 1. & Acacia catechu & Khayer & 0.0155 & 0.021 & 0 & 0 & 0 & 0 & 0.004 & 0.005 \\
\hline 2. & Adina cordifolia & Karma & 0 & 0 & 0.0005 & 0.0008 & 0 & 0 & 0.0002 & 0.0003 \\
\hline 3. & Albizia lucida & Padke & 0 & 0 & 0 & 0 & 0 & 0 & 0.015 & 0.019 \\
\hline 4. & Annona squamosa* & Sitafal & 0.0005 & 0.0006 & 0 & 0 & 0 & 0 & 0.0001 & 0.0001 \\
\hline 5. & Bombax ceiba & Simal & 0.022 & 0.029 & 0 & 0 & 0.001 & 0.0009 & 0.005 & 0.008 \\
\hline 6. & Cornea bichotoma & Bohari & 0.01 & 0.013 & 0.006 & 0.010 & 0 & 0 & 0.005 & 0.007 \\
\hline 7. & Dalbergia sissoo & Sissoo & 0.016 & 0.021 & 0 & 0 & 0 & 0 & 0.004 & 0.005 \\
\hline 8. & Disoccilum binecteriferum & Dhamina & 0 & 0 & 0.02925 & 0.049 & 0 & 0 & 0.0145 & 0.019 \\
\hline 9. & Duabanga grandiflora & Lampate & 0 & 0 & 0.0025 & 0.004 & 0 & 0 & 0.001 & 0.001 \\
\hline 10. & Ehretia elliptica & Dhadrung & 0.012 & 0.016 & 0.04 & 0.066 & 0.0015 & 0.001 & 0.023 & 0.031 \\
\hline 11. & Ficus hirta & Kashreto & 0.0025 & 0.003 & 0 & 0 & 0.01 & 0.009 & 0.003 & 0.004 \\
\hline 12. & Ficus semicordata & Khanayo & 0 & 0 & 0 & 0 & 0.075 & 0.072 & 0.018 & 0.025 \\
\hline 13. & Holarrbena pubescens & Dudhe & 0 & 0 & 0.0085 & 0.014 & 0 & 0 & 0.004 & 0.006 \\
\hline 14. & Hydrangea robusta* & Phirphire & 0 & 0 & 0.00025 & 0.0004 & 0 & 0 & 0.0001 & 0.0001 \\
\hline 15. & Litsea monopetala & Kutmero & 1.0525 & 1.409 & 0.49125 & 0.822 & 0.007 & 0.006 & 0.5105 & 0.686 \\
\hline 16. & Luculia gratissima & Kangiyo & 0.0015 & 0.002 & 0.0002 & 0.0004 & 0 & 0 & 0.0005 & 0.0007 \\
\hline 17. & Mallotus phillipinensis & Sindure & 0 & 0 & 0.0205 & 0.034 & 0 & 0 & 0.010 & 0.014 \\
\hline 18. & Melia azedirach & Bakaino & 0.001 & 0.001 & 0 & 0 & 0 & 0 & 0.0002 & 0.0003 \\
\hline 19. & Miliusa velutia & Kali kath & 0 & 0 & 0.0065 & 0.011 & 0 & 0 & 0.003 & 0.004 \\
\hline 20. & Morus alba & Kimbu & 0.0255 & 0.034 & 0 & 0 & 0 & 0 & 0.006 & 0.008 \\
\hline 21. & Murraya koenigii & Ashare & 0.017 & 0.023 & 0.25175 & 0.4210 & 0.01 & 0.009 & 0.133 & 0.178 \\
\hline 22. & Myrsine chisia & Bilauni & 0.0055 & 0.007 & 0.30625 & 0.512 & 0.006 & 0.006 & 0.156 & 0.210 \\
\hline 23. & Premna barbata & Ginderi & 0.1185 & 0.159 & 0.011 & 0.018 & 0.01 & 0.009 & 0.0375 & 0.0504 \\
\hline 24. & Trewia nudiflora & Veldar & 0.042 & 0.056 & 0.09925 & 0.166 & 0.022 & 0.021 & 0.065 & 0.088 \\
\hline
\end{tabular}


Section 2: Density and relative density of shrubs (highest and lowest density values are highlighted)

\begin{tabular}{|c|c|c|c|c|c|c|c|c|c|c|}
\hline \multirow[b]{2}{*}{ S. N. } & \multirow[b]{2}{*}{ Botanical name } & \multirow[b]{2}{*}{ Local name } & \multicolumn{2}{|c|}{ JCF (Afforested land) } & \multicolumn{2}{|c|}{ Icharni woodland } & \multicolumn{2}{|c|}{ Icharni Grassland } & \multicolumn{2}{|c|}{ Overall } \\
\hline & & & $\begin{array}{l}\text { Density } \\
\mathrm{pl} / \mathrm{m}^{2}\end{array}$ & $\begin{array}{c}\text { Rel. density } \\
\%\end{array}$ & $\begin{array}{l}\text { Density } \\
\mathrm{pl} / \mathrm{m}^{2}\end{array}$ & $\begin{array}{c}\text { Rel. density } \\
\%\end{array}$ & $\begin{array}{c}\text { Density } \\
\mathrm{pl} / \mathrm{m}^{2}\end{array}$ & $\begin{array}{c}\text { Rel. density } \\
\%\end{array}$ & $\begin{array}{l}\text { Density } \\
\mathrm{pl} / \mathrm{m}^{2}\end{array}$ & $\begin{array}{c}\text { Rel density } \\
\%\end{array}$ \\
\hline 1 & Acacia rugata & Areli & 0 & 0 & 0.5175 & 0.086 & 0 & 0 & 0.25875 & 0.035 \\
\hline 2 & Achyrantbus aspera & Apmarga & 2.3 & 0.308 & 0 & 0 & 0 & 0 & 0.575 & 0.077 \\
\hline 3 & Ageratina adenophora & Kalo banmara & 0.35 & 0.0468 & 4.375 & 0.732 & 0.2 & 0.019 & 2.325 & 0.312 \\
\hline 4 & Antidesma acidum & Jhutka amili & 0.75 & 0.100 & 0 & 0 & 0.25 & 0.024 & 0.25 & 0.033 \\
\hline 5 & Artemisia vulgaris & Pati & 0 & 0 & 0.7 & 0.117 & 8.7 & 0.841 & 2.525 & 0.339 \\
\hline 6 & Bobmeria platyphylla & Kamle & 1.75 & 0.234 & 2.825 & 0.472 & 0.45 & 0.043 & 1.9625 & 0.263 \\
\hline 7 & Calicarpa arborea & Guyalo & 0.05 & 0.006 & 0 & 0 & 0 & 0 & 0.0125 & 0.001 \\
\hline 8 & Callicarpa macrophylla & dahikamala & 2.5 & 0.335 & 3.125 & 0.523 & 1.15 & 0.111 & 2.475 & 0.332 \\
\hline 9 & Chromolaena odorata & Banmara & 0.95 & 0.127 & 3.225 & 0.539 & 0.3 & 0.029 & 1.925 & 0.256 \\
\hline 10 & Clerodendron viscosum & Bhanti & 0.65 & 0.087 & 6 & 1.003 & 0 & 0 & 3.1625 & 0.425 \\
\hline 11 & Coffea benghalensis & Baramase & 0 & 0 & 42.875 & 7.171 & 0 & 0 & 21.4375 & 2.88 \\
\hline 12 & Colebrookia oppositifolia & Dhursul & 0.55 & 0.074 & 4.95 & 0.828 & 0 & 0 & 2.6125 & 0.351 \\
\hline 13 & Debregaesia velutina & Sano tusare & 0 & 0 & 0.025 & 0.004 & 0 & 0 & 0.0125 & 0.001 \\
\hline 14 & Hyptis suaveolens & Silam & 0 & 0 & 0.025 & 0.004 & 0 & 0 & 0.0125 & 0.001 \\
\hline 15 & Lantana camara & Lantana & 0.4 & 0.053 & 0 & 0 & 0 & 0 & 0.1 & 0.013 \\
\hline 16 & Mesoneuron cuculata & Boksi kanda & 0.005 & 0.0006 & 0.1375 & 0.023 & 0 & 0 & 0.07 & 0.009 \\
\hline 17 & Mimosa pudica & Lazzawati & 0 & 0 & 0.775 & 0.130 & 0 & 0 & 0.3875 & 0.052 \\
\hline 18 & Verbena bybrida & Galaiche bogate & 0 & 0 & 0 & 0 & 0.1 & 0.009 & 0.025 & 0.003 \\
\hline 19 & Pogostemon benghalensis & $\begin{array}{l}\text { Rudilo } \\
\end{array}$ & 3.1 & 0.415 & 4.55 & 0.761 & 0.4 & 0.039 & 3.15 & 0.423 \\
\hline 20 & Sida acuta & Balu & 0 & 0 & 1 & 0.167 & 7 & 0.677 & 2.25 & 0.302 \\
\hline 21 & Solanum torvum & Binhi & 0.3 & 0.040 & 0 & 0 & 0.2 & 0.019 & 0.125 & 0.017 \\
\hline 22 & Woodfordia fruticosa & Dhairo & 0 & 0 & 0.025 & 0.004 & 0.05 & 0.005 & 0.025 & 0.003 \\
\hline 23 & Ziriphus mauritiana & Bayer & 0 & 0 & 0 & 0 & 0.5 & 0.048 & 0.125 & 0.0168 \\
\hline
\end{tabular}


Section 3: Density and relative density of herbs (highest and lowest density values are highlighted)

\begin{tabular}{|c|c|c|c|c|c|c|c|c|c|c|}
\hline \multirow[b]{2}{*}{ S.N. } & \multirow{2}{*}{ Botanical name } & \multirow{2}{*}{ Local name } & \multicolumn{2}{|c|}{ JCF (Afforested land) } & \multicolumn{2}{|c|}{ Icharni woodland } & \multicolumn{2}{|c|}{ Icharni Grassland } & \multicolumn{2}{|c|}{ Overall } \\
\hline & & & Density $\mathrm{pl} / \mathrm{m}^{2}$ & Rel. density \% & Density $\mathrm{pl} / \mathrm{m}^{2}$ & Rel. density \% & Density $\mathrm{pl} / \mathrm{m}^{2}$ & Rel. density \% & Density $\mathrm{pl} / \mathrm{m}^{2}$ & Rel. density $\%$ \\
\hline 1 & Ageratum conyzoides & Gandhe & 62.5 & 0.335 & 765.625 & 5.122 & 1063.75 & 4.118 & 664.375 & 3.571 \\
\hline 2 & Aquisetum debile & Akhle & 375 & 2.008 & 1265.625 & 8.468 & 2281.25 & 8.831 & 1296.875 & 6.971 \\
\hline 3 & Canotis cristata & Kane ghans & 812.5 & 4.350 & 343.75 & 2.300 & 375 & 1.452 & 468.75 & 2.519 \\
\hline 4 & Centella asiatica & Ghodtapre & 156.25 & 0.836 & 0 & 0 & 0 & 0 & 39.0625 & 0.210 \\
\hline 5 & Cirsium walichii & Gainde kanda & 0 & 0 & 0 & 0 & 156.25 & 0.605 & 39.0625 & 0.210 \\
\hline 6 & Colocasia esculenta & Karkalo & 343.75 & 1.840 & 46.875 & 0.314 & 0 & 0 & 109.375 & 0.588 \\
\hline 7 & Curcuma species & Ban beshar & 13.75 & 0.074 & 0 & 0 & 0 & 0 & 3.4375 & 0.018 \\
\hline 8 & Cynodon dactylon & Dubo & 187.5 & 1.004 & 578.125 & 3.868 & 0 & 0 & 335.9375 & 1.806 \\
\hline 9 & Cyperus species & Mothe & 0 & 0 & 109.375 & 0.732 & 156.25 & 0.605 & 93.75 & 0.504 \\
\hline 10 & Desmodium species & Badam pate & 0 & 0 & 31.25 & 0.209 & 0 & 0 & 15.625 & 0.003 \\
\hline 11 & Digitaria species & Pani banso & 0 & 0 & 93.75 & 0.627 & 0 & 0 & 46.875 & 0.252 \\
\hline 12 & Digitaria species & Phurke banso & 0 & 0 & 78.125 & 0.523 & 0 & 0 & 39.0625 & 0.210 \\
\hline 13 & Eleusine indica & Kode banso & 0 & 0 & 203.125 & 1.359 & 0 & 0 & 101.5625 & 0.546 \\
\hline 14 & Eragrostis unioloides & Banso & 7093.75 & 37.981 & 2778.125 & 18.587 & 4687.5 & 18.146 & 4334.375 & 23.298 \\
\hline 15 & Flemingia strobilifera & Bhatmas pate & 0 & 0 & 328.125 & 2.195 & 93.75 & 0.363 & 187.5 & 1.008 \\
\hline 16 & Hemertheria comparusa & Ghode dubo & 156.25 & 0.836 & 109.375 & 0.732 & 62.5 & 0.242 & 109.375 & 0.588 \\
\hline 17 & Imperata cylindrica & Siru & 0 & 0 & 0 & 0 & 6406.25 & 24.799 & 1601.5625 & 8.608 \\
\hline 18 & Kalanchoe spathulata & Hatti kane & 0 & 0 & 46.875 & 0.314 & 0 & 0 & 23.4375 & 0.126 \\
\hline 19 & Oxalis latifolia & Chari amilo & 1156.25 & 6.191 & 187.5 & 1.254 & 0 & 0 & 382.8125 & 2.057 \\
\hline 20 & Phragmites karka & Narkot & 0 & 0 & 1.875 & 0.012 & 0 & 0 & 0.9375 & 0.005 \\
\hline 21 & Rernwardtia trigyan & Pauli ghans & 312.5 & 1.673 & 0 & 0 & 0 & 0 & 78.125 & 0.420 \\
\hline 22 & Rungia parviflora & ukuchi jhar & 0 & 0 & 140.625 & 0.941 & 0 & 0 & 70.3125 & 0.378 \\
\hline 23 & Saccharum spontaneum & Kans & 0 & 0 & 31.25 & 0.209 & 9250 & 35.808 & 2328.125 & 12.514 \\
\hline 24 & Separis verticulata & Sali banso & 0 & 0 & 0 & 0 & 31.25 & 0.121 & 7.8125 & 0.042 \\
\hline 25 & Vitex cerdivus & Kutile kosa & 31.25 & 0.167 & 0 & 0 & 0 & 0 & 7.8125 & 0.042 \\
\hline 29 & Unknown $1 *$ & Amala jhar* & 0 & 0 & 0 & 0 & 62.5 & 0.242 & 15.625 & 0.002 \\
\hline 26 & Unknown2* & Chiple jhar* & 0 & 0 & 31.25 & 0.209 & 0 & 0 & 15.625 & 0.084 \\
\hline 30 & Unknown3* & Kamle ghans* & 0 & 0 & 0 & 0 & 125 & 0.484 & 31.25 & 0.168 \\
\hline 27 & Unknown4* & Khursani jhar* & 0 & 0 & 0 & 0 & 1.25 & 0.005 & 0.3125 & 0.001 \\
\hline 33 & Unknown5* & Mushroom* & 0 & 0 & 46.875 & 0.314 & 0 & 0 & 23.4375 & 0.126 \\
\hline 28 & Unknown6* & Pirrye jhar* & 0 & 0 & 109.375 & 0.732 & 0 & 0 & 54.6875 & 0.294 \\
\hline 31 & Unknown1** & Unknown1** & 0 & 0 & 0 & 0 & 1.25 & 0.005 & 0.3125 & 0.001 \\
\hline 32 & Unknown $2 * *$ & Unknown $2 * *$ & 0 & 0 & 31.25 & 0.209 & 0 & 0 & 15.625 & 0.084 \\
\hline 34 & Unknown3** & Unknown3** & 0 & 0 & 109.375 & 0.732 & 0 & 0 & 54.6875 & 0.294 \\
\hline
\end{tabular}


Section 4: Density and relative density of ferns (highest and lowest density values are highlighted)

\begin{tabular}{|c|c|c|c|c|c|c|c|c|c|c|}
\hline \multirow[b]{2}{*}{ S.N } & \multirow[b]{2}{*}{ Botanical name } & \multirow[b]{2}{*}{ Local name } & \multicolumn{2}{|c|}{ JCF (Afforested land) } & \multicolumn{2}{|c|}{ Icharni woodland } & \multicolumn{2}{|c|}{ Icharni Grassland } & \multicolumn{2}{|c|}{ Overall } \\
\hline & & & $\begin{array}{l}\text { Density } \\
\mathrm{pl} / \mathrm{m}^{2}\end{array}$ & $\begin{array}{c}\text { Rel. } \\
\text { density \% }\end{array}$ & $\begin{array}{l}\text { Density } \\
\mathrm{pl} / \mathrm{m}^{2}\end{array}$ & $\begin{array}{c}\text { Rel. } \\
\text { density \% } \\
\end{array}$ & $\begin{array}{l}\text { Density } \\
\mathrm{pl} / \mathrm{m}^{2}\end{array}$ & $\begin{array}{c}\text { Rel. } \\
\text { density \% }\end{array}$ & $\begin{array}{l}\text { Density } \\
\mathrm{pl} / \mathrm{m}^{2}\end{array}$ & $\begin{array}{c}\text { Relative } \\
\text { density \% }\end{array}$ \\
\hline 1 & Diplazium esculentum & Neuro & 500 & 2.677 & 1671.875 & 11.186 & 0 & 0 & 960.93 & 5.165 \\
\hline 2 & Lepisorus bicolor & Dhule uneu & 2687.5 & 14.389 & 2500 & 16.726 & 0 & 0 & 1921.8 & 10.330 \\
\hline 3 & Pterish vittata & Bish uniu & 1156.25 & 6.191 & 187.5 & 1.254 & 0 & 0 & 382.81 & 2.058 \\
\hline 4 & Tectoria macrodonta & Kale neuro & 3500 & 18.740 & 796.875 & 5.331 & 343.75 & 1.331 & 1359.3 & 7.307 \\
\hline
\end{tabular}

Section 5: Density and relative density of climbers and creepers (highest and lowest density values are highlighted)

\begin{tabular}{|c|c|c|c|c|c|c|c|c|c|c|}
\hline \multirow[b]{2}{*}{ S.N. } & \multirow[b]{2}{*}{ Botanical name } & \multirow[b]{2}{*}{ Local name } & \multicolumn{2}{|c|}{ JCF (Afforested land) } & \multicolumn{2}{|c|}{ Icharni woodland } & \multicolumn{2}{|c|}{ Icharni Grassland } & \multicolumn{2}{|c|}{ Overall } \\
\hline & & & $\begin{array}{l}\text { Density } \\
\mathrm{pl} / \mathrm{m}^{2}\end{array}$ & $\begin{array}{c}\text { Rel. } \\
\text { density \% }\end{array}$ & $\begin{array}{l}\text { Density } \\
\mathrm{pl} / \mathrm{m}^{2}\end{array}$ & $\begin{array}{c}\text { Rel. } \\
\text { density \% }\end{array}$ & $\begin{array}{l}\text { Density } \\
\mathrm{pl} / \mathrm{m}^{2}\end{array}$ & $\begin{array}{l}\text { Rel. density } \\
\%\end{array}$ & $\begin{array}{l}\text { Density } \\
\mathrm{pl} / \mathrm{m}^{2}\end{array}$ & $\begin{array}{c}\text { Rel. } \\
\text { density \% }\end{array}$ \\
\hline 1 & Bridelia retusa & Gayo & 0.001 & 0.001 & 0.03025 & 0.050 & 0.0215 & 0.021 & 0.02075 & 0.028 \\
\hline 2 & Ceropegia pubescens & Ban simi & 0 & 0 & 0.00025 & 0.0004 & 0 & 0 & 0.00012 & 0.0001 \\
\hline 3 & Coccinea grandis & Golkakri & 0 & 0 & 0 & 0 & 0.0105 & 0.010 & 0.00262 & 0.003 \\
\hline 4 & Dioscorea bulbifera & Githa & 0.0035 & 0.005 & 0.00025 & 0.0004 & 0 & 0 & 0.001 & 0.001 \\
\hline 5 & Dioscorea deltoides & Ban tarul & 0.0055 & 0.007 & 0 & 0 & 0 & 0 & 0.00137 & 0.002 \\
\hline 6 & Jinospora sinensis & Batul pate & 0.0015 & 0.002 & 0.0625 & 0.104 & 0 & 0 & 0.03162 & 0.042 \\
\hline 7 & Mikania micrantha & Mile a minute & 0.0225 & 0.030 & 0.2195 & 0.367 & 0.0405 & 0.039 & 0.1255 & 0.169 \\
\hline 8 & Parthenocissus semicordata & Charchare & 1.119 & 1.498 & 0.33475 & 0.560 & 0.036 & 0.035 & 0.45612 & 0.613 \\
\hline 9 & Pericampylus glaucus & Pate lahara & 0.016 & 0.021 & 0.1255 & 0.210 & 0.0015 & 0.001 & 0.06712 & 0.090 \\
\hline 10 & Piper longum & Pipla & 1.253 & 1.677 & 0.25325 & 0.423 & 0 & 0 & 0.43987 & 0.591 \\
\hline 11 & Poncirus trifolia & Tin pate & 0.001 & 0.001 & 0.001 & 0.002 & 0.628 & 0.608 & 0.15775 & 0.212 \\
\hline 12 & Stephania elegans & Batule lahara & 0.0055 & 0.007 & 0.00375 & 0.006 & 0.002 & 0.002 & 0.00375 & 0.005 \\
\hline 13 & Tetrastigma serrulatum & Bakhre lahara & 0.0055 & 0.007 & 0.021 & 0.035 & 0.002 & 0.002 & 0.01237 & 0.017 \\
\hline 14 & Trachelospermum fragrans & Dudhe lahara & 0.01 & 0.0134 & 0.14 & 0.234 & 0 & 0 & 0.0725 & 0.097 \\
\hline 15 & Trichosanthes wallichiana & Indreni & 0.0005 & 0.0006 & 0 & 0 & 0 & 0 & 0.00012 & 0.0001 \\
\hline 16 & Unknown & Unknown & 0.0005 & 0.0006 & 0 & 0 & 0 & 0 & 0.00012 & 0.0001 \\
\hline
\end{tabular}




\section{Annex 2: Some Photo plates on Mikania}

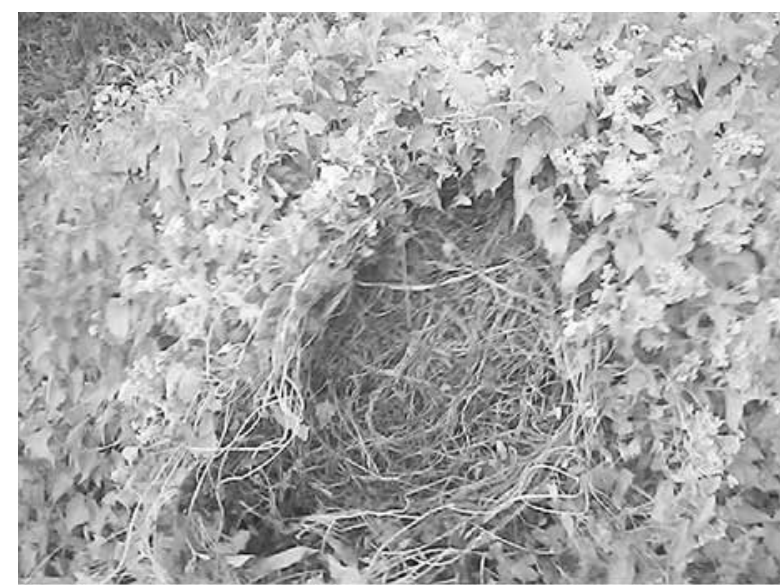

Dead branches of Mikania in touch with interface and laying in between the face and ground

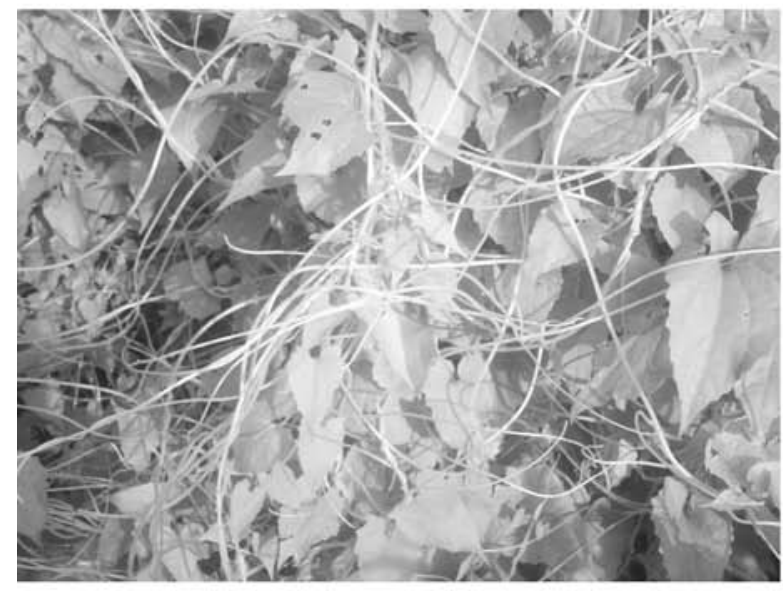

Cuscuta accession on Mikania

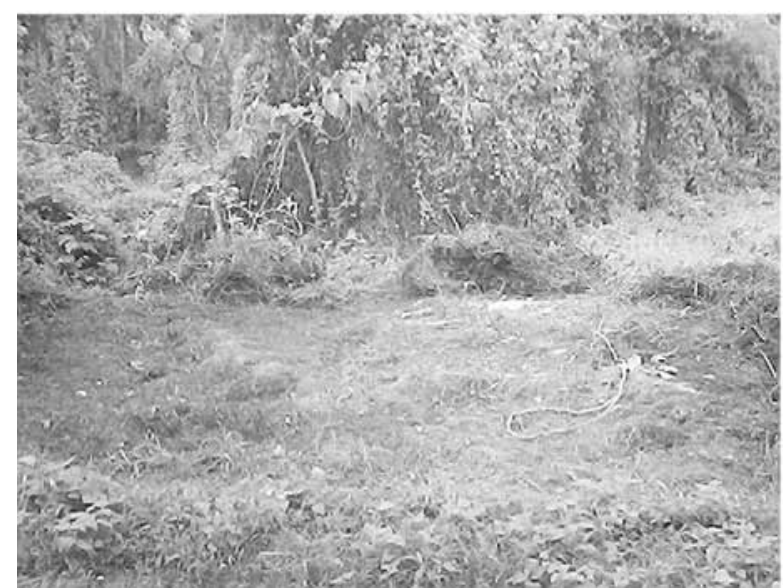

Ground surface after removing the mulch

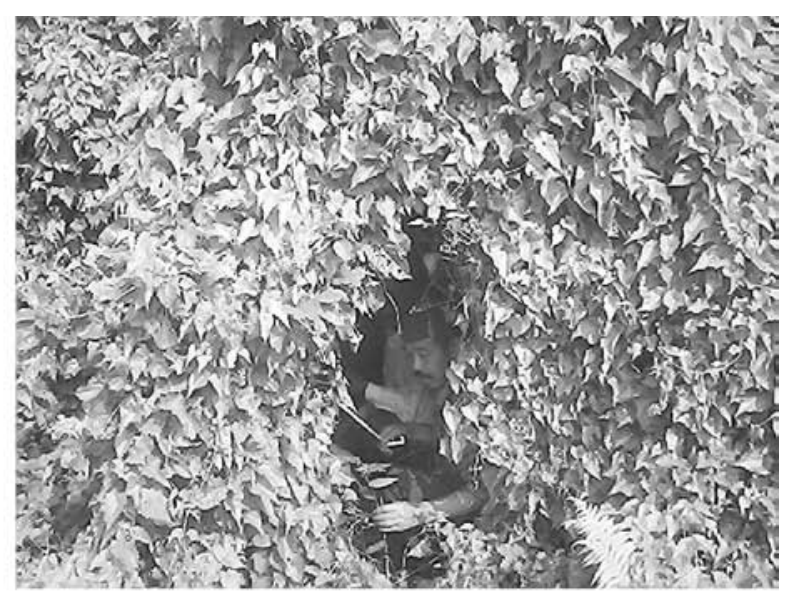

Mikania invasion on sissoo tree forming shed

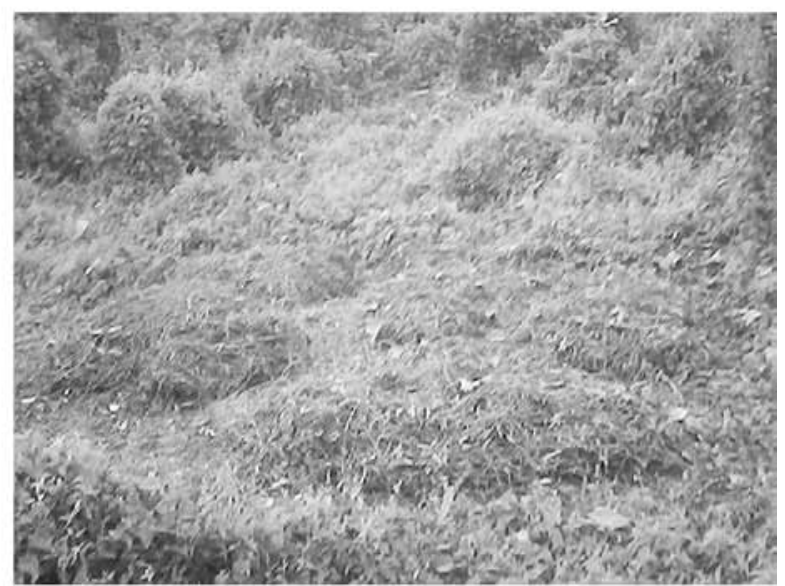

Mulching on Mikania creeper kept for three months

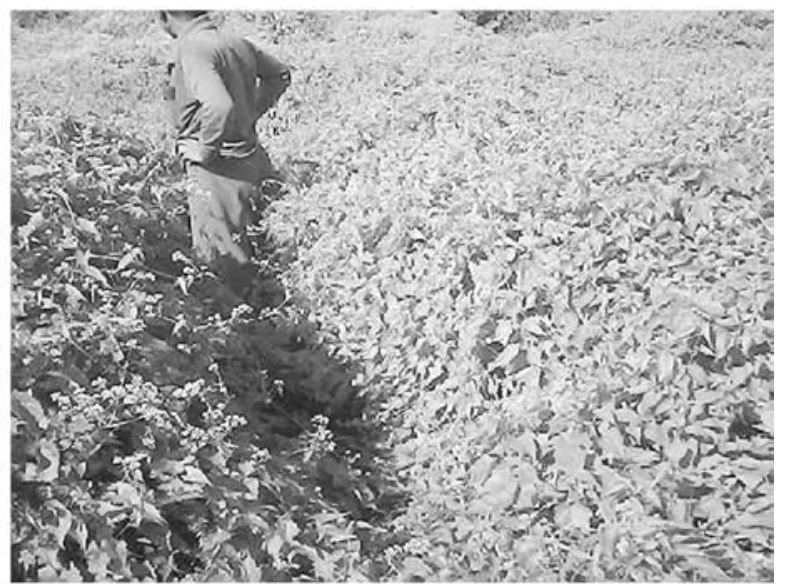

Grassland smothered by Mikania 